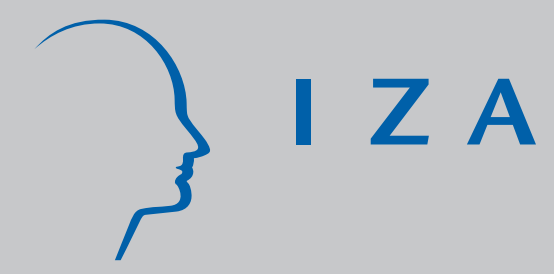

IZA DP No. 557

Reducing Hours of Work: Does Overtime Act as a Brake Upon Employment Growth? An Analysis by Gender for the Case of Italy

Gianna C. Giannelli

Cristina Braschi

August 2002 


\title{
Reducing Hours of Work: Does Overtime Act as a Brake Upon Employment Growth? An Analysis by Gender for the Case of Italy
}

\author{
Gianna C. Giannelli \\ University of Florence, CHILD and IZA Bonn \\ Cristina Braschi \\ University of Florence
}

Discussion Paper No. 557

August 2002

IZA

P.O. Box 7240

D-53072 Bonn

Germany

Tel.: +49-228-3894-0

Fax: +49-228-3894-210

Email: iza@iza.org

This Discussion Paper is issued within the framework of IZA's research area The Future of Labor. Any opinions expressed here are those of the author(s) and not those of the institute. Research disseminated by IZA may include views on policy, but the institute itself takes no institutional policy positions.

The Institute for the Study of Labor (IZA) in Bonn is a local and virtual international research center and a place of communication between science, politics and business. IZA is an independent, nonprofit limited liability company (Gesellschaft mit beschränkter Haftung) supported by the Deutsche Post AG. The center is associated with the University of Bonn and offers a stimulating research environment through its research networks, research support, and visitors and doctoral programs. IZA engages in (i) original and internationally competitive research in all fields of labor economics, (ii) development of policy concepts, and (iii) dissemination of research results and concepts to the interested public. The current research program deals with (1) mobility and flexibility of labor, (2) internationalization of labor markets, (3) welfare state and labor market, (4) labor markets in transition countries, (5) the future of labor, (6) evaluation of labor market policies and projects and (7) general labor economics.

IZA Discussion Papers often represent preliminary work and are circulated to encourage discussion. Citation of such a paper should account for its provisional character. A revised version may be available on the IZA website (www.iza.org) or directly from the author. 


\section{ABSTRACT}

\section{Reducing Hours of Work: Does Overtime Act as a Brake Upon Employment Growth? An Analysis by Gender for the Case of Italy}

In recent years the question of overtime work has become increasingly relevant as part of the wider issue of the reduction in the working day. A direct relation between policies aiming at reducing working hours, and increases in overtime work neutralising their beneficial effects on employment, has been envisaged by those opposing such policies.

We investigate this issue using microdata by the Bank of Italy. In Italy, the incidence of overtime work among male dependent workers is relatively high. In particular, we seek to ascertain if, for Italy too, the fear that a reduction in working hours could give rise to a substitution of overtime work for new jobs is legitimate.

We estimate the probability of working overtime, together with equations for overtime hours of work, using different econometric models, both for cross-section (probit, tobit) and panel data (conditional fixed effects logit). Among several other variables, we control for wages and normal hours. We are particularly interested in exploring differences by sex. Overtime has always been studied over selected samples of male employees working in the private sector. Of course, focusing on workers who are most likely to work overtime will yield the result of a relatively large "substitution" effect. We show that extending the analysis to a more realistic labour market that includes female workers, this effect may become relatively modest for some specific policy measures. This result is robust across different sampling assumptions and model specifications, thus giving support to the hypothesis that the policies aiming at reducing the normal working day may have positive employment effects.

JEL Classification: J21, J22, J23

Keywords: overtime work, reducing contractual hours, employment

Gianna Claudia Giannelli

University of Florence

Via S. Caterina d'Alessandria 3

50129 FIRENZE

Italy

Tel.: +39055 4622926

Fax: +39055 472102

Email: giannelli@studistato.unifi.it 


\section{Introduction}

Limiting overtime is one of the aims of working hour reduction. Trade unions press for jobs "taken up" by workers who regularly work overtime to be freed up.

Some countries have already implemented and other are experimenting with working hour (including overtime) reduction policies with the aim of encouraging work-sharing. Generally speaking, however, economists are sceptical about the effectiveness of this policy.

In Italy, paid overtime hours have been a permanent feature of employment, both to meet the firms' need to respond to product demand shocks, and the workers' willingness to supplement labour income. Policies to reduce working hours, however, have come under sharp criticism because they allegedly: 1) cause a rise in labour costs estimated at around 10-12\% (according to the firms' national association); 2) are a cause of reduced company organisational flexibility; 3) limit the workers' freedom to choose how much to work; 4) are an excuse for firms to resort more often to overtime work.

The debate on these issues, even if quite heated, is not supported by scientific economic analyses. To our knowledge, in fact, overtime work has never been studied for Italy. Following the empirical literature on overtime work in other European countries, we analyse data released by the Bank of Italy in order to identify the determinants of paid overtime work in Italy. In particular, we seek to ascertain if the fear that a reduction in working hours could give rise to a "substitution" effect between overtime and new jobs is legitimate. We examine which type of worker is more likely to work overtime and, of those that do so, who does so most. We use the estimated models to perform some simple policy experiments on the reduction of the working day that, under different behavioural assumptions, allow to measure the range of variation of the "substitution" effect on employment.

In Europe, and particularly in Italy where the participation rate is low, the future of employment growth largely relies on female participation. Overtime has always been studied over selected samples of male employees working in the private sector. Of course, focusing on workers who are most likely to work overtime, will yield the result of a relatively large "substitution" effect. We think this is not a correct way to study the trade-off between overtime and the number of employed people. We therefore extend our analysis to females and to all sectors where overtime work is regularly observed, including the public sector. In fact, we show that widening the analysis to a more realistic labour market that includes female employees, the "substitution effect" is largely reduced.

We make a variety of sampling assumptions (where the most extreme ones may be used as benchmark for comparison) and then estimate the relation between standard hours and hourly wage with overtime hours by means of probit and tobit models on a cross-section for the year 2000. We then use the estimated coefficients to calculate the range of variation of the "substitution" effect. Finally we use panel data to test the robustness on our results under the assumption of the presence of fixed effects.

The paper is structured as follows. Section 2 briefly reviews some recent literature on overtime. Section 3 gives some evidence on overtime in Italy. Section 4 
describes our data, models, results and measures of the effects of different policy experiments. Section 5 concludes.

\section{The literature on overtime work}

Many theoretical studies have been carried out on the consequences of a reduction in working hours on overtime hours and on employment levels (see Ehrenberg, 1971, Hart, 1987, Camfors and Hoel, 1988 and 1989, Hunt 1996 and 1999, among many others). The standard approach is to consider first the case of cost minimisation and output constant, and then profit maximization with variable output. Calmfors and Hoel (1988), for example, show that, under certain conditions, the firm, when faced by a reduction in working hours, reacts by reducing its workforce and increasing overtime. Hunt (1999) examines the effect a reduction would have on marginal costs, stressing how, after reducing working hours, it is cheaper for a company to increase overtime hours than to take on new labour. Recent empirical studies give contrasting results: on the basis of data for Germany, Bauer and Zimmermann (1999) show that, since those who work overtime are mainly skilled workers, a general reduction in overtime will lead to less production and hence also to a decline of unskilled employment. Trejo (1993), for Great Britain, shows that a reduction in working hours increases overtime levels. Bell and Hart (1999), using data for England, discover that a reduction in working hours causes a drop in overtime. Hunt (1999), with Panel data for Germany, shows that a reduction of one hour in regular working hours brings about a fall of between 0.88 and 1 hour in normal working hours (viz. including overtime) and therefore has a limited effect on overtime. Kalwij and Gregory (2000) investigate the case of Britain over the period 1975-1999. Their results show that changes in the job mix across the economy, from high to low overtime jobs rather than within-job changes, account for most of the overtime work decline over the 90's. Pannenberg and Wagner (2001) show on data for West Germany and Great Britain that the decrease in paid overtime affects negatively monthly labour earnings and that workers who have to switch from paid overtime into "working time accounts" suffer from significant relative income losses. Frederiksen, Graversen and Smith (2001) show that labour supply elasticities are highly sensitive to the inclusion of information on overtime work and secondary job and fixed costs. Trejo (2001) examines the effect of statutory overtime premium on the workweek length and finds that this decision does not produce a discernible impact on overtime hours. Crepon and Kramarz (2002), studying the impact of mandatory reduction of the working week in France, find that a one hour reduction had a negative impact on employment during the 80's.

\section{Overtime work in Italy}

Overtime work has always been a feature of the Italian labour market. Always considered a powerful tool wielded by companies to obtain flexibility, it still plays a prominent part in regulating the production process. Many different factors have favoured the continued expansion of overtime: it has emerged mainly as a response to the changing needs of the marketplace, and its use has especially been determined by peaks in production, the acquisition of new orders and the need to satisfy the rise in demand as quickly as possible. 
The year 1955, when the first basic amendment to the former legislation on overtime was introduced ${ }^{1}$, marks an important starting point for the analysis of this phenomenon. Data supplied by the Ministry of Labour for that year, show that Fiat in Turin had more than 400,000 hours of overtime worked per month and Lauda more than 60,000. Data of the National Statistical Office (ISTAT) show that the proportion of overtime as a percentage of total working hours doubled between 1975-84 and 1985-1995, rising from $2 \%$ to $4 \%$.

The use of overtime has not declined in recent years and it has been resorted to more often in periods of economic upturn.

\section{Fig. 1}

Figure 1 shows the percentage of workers who work overtime on the total number of employees having one job, working full-time all over the year, with a permanent contract ${ }^{2}$. As it can be seen, overtime incidence has varied cyclically ${ }^{3}$, reaching the highest value in 1989 and the lowest one in 1993. Overtime incidence for women is around $57 \%$ that of males on average. Note that this percentage reaches its highest value $(61 \%)$ at the end of the downturn. This might be interpreted with the fact that female overtime work is always around its physiologic value, and therefore it is less variable with respect to males'. The same assumption might help to explain also the two-year lag response with respect to males to the cyclical inversion of 1993.

Figure 2 plots the weekly average number of overtime hours worked by those who work overtime. This number fluctuates between $3 \frac{1}{2}$ and 5 hours for women and 5 and 6 for men. Female supply of overtime hours reacts with a lag to the economic upturn, in such a way that the gender gap increases pro-cyclically. This evidence, as well, confirms the fact that during the upswing firms resort to male overtime work first, and only afterwards to females' when the positive trend has consolidated.

\section{Figure 2}

Figure 3 shows that the average share of overtime hours for workers who work overtime ranges from $13 \%$ to $9 \%$, with a greater variation for women. The gender gap tends to decrease near the peaks of the economic cycle.

Fig. 3

The average number of weekly total and standard hours declined steadily over the observation period ${ }^{4}$. The distinction by gender (Fig. 4) reveals that the decline is

\footnotetext{
${ }^{1}$ The first law fixing the upper limit to the working day to 8 hours passed in 1923 . The first amendment regarding overtime work forbids its regular use. Employers are obliged to declare the number of overtime hours supplied by workers to the Labour Inspectorate within 24 hours. A clause, however, allows its regular use in "cases of exceptional demand increases, when it is not possible to hire new workers". This clause has, as a matter of fact, allowed its extensive use in subsequent years. See Appendix 1.

${ }^{2}$ All data are weighted.

${ }^{3}$ The GDP time series is reported in Appendix 2.

${ }^{4}$ Standard hours are defined as the difference between total hours and the number of hours of overtime work.
} 
dragged by female workers: the decrease in their standard and total hours amounts to 3 hours, whereas males' hours have declined by just $1 / 2$ hour. Moreover, it must be noticed that the margin of overtime is nearly constant for females, whereas for males, besides being wider, is also sensitive to the cycle.

Fig. 4

As far as overtime compensation is concerned, a distinguishing feature of the Italian system is that overtime hours involve lower costs than do normal hours. This is one of the reasons why companies have often chosen to respond to substantial market pressures by massive use of overtime work. In so doing, some of them have limited hiring of labour and worked understaffed for long stretches.

An example of this fact is given in Table 1, which shows the composition of pay of blue collars in the metallurgic and mechanical sector.

Even if the direct component of hourly pay is increased by half, one hour of overtime work is still cheaper for the company than one hour of regular labour. This is because some of the direct components of pay and all the indirect ones are not included in the cost of overtime. Indeed, the indirect components (holiday pay, thirteenth month bonus, bank holidays, pay in lieu of reduced hours, severance payment etc.), which make up a large part of normal wages, are substantially higher than the total contracted amount required for overtime. Even if many companies do calculate overtime on the total hourly pay and not just the contractnegotiated items, there is still a disproportionate gap between the cost of regular and overtime labour.

The male perspective in discussions about the use of overtime, has led to conclude that one of the reasons such an indiscriminate use of overtime by companies is possible is the ready and ever-growing willingness of the labour force to work beyond normal hours. Indeed, overtime work makes working times a choice variable for males. Moreover, male workers get used to higher levels of pay, since it is not at all easy to give up this source of supplementary income.

This way of reasoning, however, does not apply to females, because their problem of time allocation between the family and the market and their opportunity cost of time are completely different from those of males.

This is reflected by the data presented above, and makes the argument that reducing working hours would lead to a widespread increase in overtime work, thus neutralising the beneficial effects on employment, less credible.

\section{Factors determining overtime work - an empirical analysis on cross- section and panel data for Italy.}

The aim of this section is to examine which factors determine the amount of overtime worked by an employee and use our estimates to calculate the impact of a reduction in working hours on overtime.

Two questions are raised. The first is whether a worker will decide to work overtime (incidence of overtime), and the second concerns how much weekly overtime she/he will work .

We first use cross-section data to examine how probable it is that an employee works overtime given certain socio-economic factors regarding the worker 
himself. To do so, we employ the Probit model of probability. Secondly, we employ the Tobit model to estimate the amount of hours of overtime supplied conditional (and unconditional) on the probability of making overtime. Thirdly, we use our estimates to calculate the impact of a reduction in working hours on overtime and therefore the amount of potential new employment eroded by overtime. We then turn to panel data and estimate a fixed effect specification of the model. The conditional fixed effect logit model (Chamberlain, 1980), in particular, allows us to evaluate the robustness of the cross-section results once heterogeneity due to the fixed effects is taken care of.

\subsection{Data and sample}

The analysis is conducted on a cross-section and on panel data. All data are drawn from the Bank of Italy sample survey on the family budgets of Italian households. The cross-section refers to year 2000. The survey, covering 8001 families, 22268 individuals and 13814 income earners, provides information on a number of relevant variables, some relating to the household, some to the individuals and their labour market position ${ }^{5}$.

The section of the questionnaire of most relevance to our problem contains information on total (including overtime) weekly average hours worked by employees and on weekly average number of paid overtime hours worked in 2000.

As far as panel data is concerned, the sample is extracted from the so called "historical archive" of the survey on family budgets 6 . We have built a sample based on three waves of the panel $(1995,1998,2000)$ even if it would have been possible to have a longer one. This is because the use of a longer panel would have drastically reduced the number of observations ${ }^{7}$.

The samples, both for the cross-section and the panel data analysis, consist of all employees $^{8}$, who have just one job, who work all months of the year, who have a permanent full-time contract. Despite the fact we keep public workers, we discard teachers, for whom the concept of overtime is hard to assess ${ }^{9}$.

\subsection{The cross-section analysis}

After the sample selection, the sample for the year 2000 consists of 4234 individuals: 2893 men and 1341 women. On this sample we estimate probit and tobit models.

The dependent variable is dicothomous for the probability of working overtime and discrete (number of hours of overtime worked) for the Tobit model. We are mainly interested in the effects on overtime work of the hourly wage (HWAGE) and standard working hours (HSTAN, excluding, that is, overtime). The former we calculated by using the variables for total yearly income and total number of hours

\footnotetext{
${ }^{5}$ The survey, which is biannual, began in 1965 , but only since 1987 , when it started to collect information on hours of work, it has been extensively used for research on the Italian labour market. Starting from 1989 a panel data set is also collected.

${ }^{6}$ Figures 1-4 in section 3 are based on the cross-section yearly data contained in this archive.

${ }^{7}$ Only one fourth of the families in the survey are panel families. This fact together with a physiological attrition rate limits the number of usable waves to three, if one wants to have a reasonable number of observations.

${ }^{8}$ See Appendix 3 for further details on the selection of the sample.

${ }^{9}$ University teachers and academics could not be excluded, since they are grouped together with managers of private companies.
} 
worked per week ${ }^{10}$. To calculate the latter, we subtracted the hours of overtime worked per week from the total hours worked per week ${ }^{11}$ since the total number of hours worked per week in the survey included overtime.

Unfortunately, the survey does not distinguish between overtime and regular compensation, and we are forced to assume that overtime and regular labour are paid at the same rate. Relying on the evidence of the previous section, however, we can justify the use of the same hourly wage for the two types of labour on the ground that one hour of overtime work in Italy is not, on average, more expensive for the firm than one hour of regular work. From the supply side, if workers are assumed not to be myopic (in the sense that they realise that, not withstanding the increase in the direct component of overtime pay, the absence of the indirect components make overtime less attractive than regular work for them as well), overtime work should not be seen as better paid from them too.

Not all employees in the sample so far defined, however, may have the chance to work overtime. We assume that employees whose standard hours are lower than 30 hours per week do not have the chance to work overtime ${ }^{12}$.

In order to allow the analysis some flexibility, we estimate the models on two samples selected on the basis of the standard hours of work declared by the employee. The looser sample consists of employees whose standard hours are greater than 30 whereas the tighter one selects employees whose standard hours are greater than 35 .

The expectation is that in the looser sample the probability to work overtime (and the number of hours of overtime work) will be greater than in the tighter one, since employees who have a shorter standard working week (typically in the insurance sector, for example) may be assumed to have a lower marginal disutility of work than employees with longer working hours.

Moreover, since $16.5 \%$ of the employees declare HSTAN greater than 40 , we interpret this as an indication of the existence of unpaid overtime ${ }^{13}$. In order to separate the effect of unpaid overtime from the effect of the normal standard hours (assumed to be 40 on average) on paid overtime we split the HSTAN variable in two parts: HSTAN1 which is truncated to 40 hours if the employee works more than 40 hours and HDIF40 which measures the difference between the number of standard hours and 40 if the standard hours worked are greater than $40^{14}$. This splitting procedure would be correct under the assumption that a reduction in the normal working week does not affect unpaid overtime. May this assumption be plausible or not, the coefficients of this model would measure the maximum potential effect on paid overtime of a reduction in normal hours under the extreme hypothesis that employees who normally work more than 40 hours per week do not change their supply of unpaid overtime.

The other explanatory variables control for individual and family characteristics such as age, marital status, area of residence, number of income earners in the family, education, sector of employment and professional position. An examination of the descriptive statistics of the variables used in the analysis gives some first results worthy of comment (see Appendix 4).

\footnotetext{
${ }^{10}$ Hourly wage $=$ annual income/(total hours*52), 52 being the number of weeks in a year.

${ }^{11}$ standard hours $=$ total hours - overtime hours.

${ }^{12}$ This assumption, dictated by the observation of the data on hours worked, is also used in the majority of the cited studies on overtime work.

${ }^{13}$ Unfortunately there is non direct question on unpaid overtime work in the questionnaire.

${ }^{14}$ HSTAN1=HSTAN IF HSTAN $<=40$; HSTAN1=40 IF HSTAN $>40$; HDIF40=HSTAN-40 IF HSTAN $>40$
} 
Tables A4.1 and A4.2 indicate that no less than $34 \%$ of males had the chance of working overtime, whereas the figure for females is $20 \%$.

Comparing the average values of the variables relating to the group of workers who work overtime (paid) with those who do not, we note, for instance, how for those who work overtime the standard hours are fewer (37.8 for males and 37.21 for females) than for those who do no overtime (41 and 39.5 respectively). This is a significant result that will later be gone into in greater depth in the econometric analysis.

Average overtime hours for those who worked overtime were 4.5 for males and 3.5 for females.

Among those who do overtime, $78.6 \%$ are men while the percentage of men who do not work overtime drops to 64\%. HWAGE does not differ significantly among the two groups, although we observe the usual gender gap (around 14\%).

These first indications would confirm the general description of the phenomenon presented in section 3. Males have more probability of working overtime than females and females work less overtime per week when they take the chance.

\subsubsection{Results: marginal effects}

We shall now examine the results of the Probit and Tobit models, referred to the range of all employed workers corresponding to the selection criteria. The coefficients and the standard errors for all, males and females appear in Tables A4.3, A4.4 and A4.5 in Appendix 4.

The influence of standard hours and hourly wage are highly significant. Table 2 reports the marginal effects derived from the estimated Probit model and Table 3 the unconditional expected values ${ }^{15}$ derived from the estimated Tobit.

Table 2 and 3

Let us first examine the relationship between workers' standard hours and the amount of overtime they do. HSTAN has a negative coefficient, confirming the existence of a certain degree substitutability between overtime and regular work. The size of the effects depends on the selected samples (i.e. on the individuals we have assumed to have the chance to work overtime on the basis of their standard hours). According to the Probit estimates, a one hour drop in normal working hours raises the overtime probability by 4 percentage points approximately if HSTAN is greater than 30 and by 2 percentage points if HSTAN is greater than 35 , thus confirming the assumption of the increasing marginal disutility of work. The effects double (HSTAN1) under the assumption that unpaid overtime is separated from HSTAN in the individual's decision. The distinction by gender, reveals that the effects for males is twice as big that for females for each sample selection. The estimated Tobit unconditional expected values show that a one hour drop in normal working hours raises overtime by 0.16 of an hour if HSTAN is greater than 30 and by 0.07 if HSTAN is greater than 35 . For males a one hour drop in normal working hours raises overtime by 0.19 of an hour if HSTAN is greater than 30 and by 0.1 if HSTAN is greater than 35 , whereas for females the figures are 0.1 and 0.02 respectively. The effects in all cases double for HSTAN1. Let us now examine the relationship between workers' pay and overtime work. The results point to a reduction in overtime hours as the hourly pay rises, thus

${ }^{15}$ The unconditional expected value is the average effect that can be attributed to each individual in the sample. 
indicating the predominance of the income effect. More exactly, using the Tobit unconditional expected values to calculate the elasticities, for a $1 \%$ increase in hourly pay, overtime hours drop by $-0.68 \%$ if HSTAN is greater than 30 and $0.78 \%$ if it is greater than 35 . The Probit marginal effects are on average of a one percentage point decrease in the probability of working overtime for an half euro (1000 of old Italian liras) increase in the hourly wage, a bit more for males a bit less for females.

\subsubsection{Policy experiments on the impact of a reduction in hours of work}

These results can be seen in the light of the debate on working hour reduction. As we have seen, several studies give support to the idea of a certain degree of substitutability between regular working hours and overtime; in other words that some regular hours could be replaced by overtime hours instead of new jobs. This conclusion seems to be confirmed by our analyses.

Our next question is: what impact would a reduction in working hours have on employment? In other words, we aim to measure, under our sampling assumptions, how much overtime work would be induced by a reduction in regular working hours and transform this in equivalent new jobs lost (dividing extra overtime hours by the sample average standard hours after the reduction).

This method is valid only under the assumption that individuals do not change preferences and behaviour after the implementation of the new policy measure ${ }^{16}$.

We consider the effects of three different policy measures, and distinguish them by gender. First, a generalised reduction of one hour in the working week. This means, in other words, a one hour reduction in contractual hours in all sectors and professions applied to all individuals who are allowed to work overtime (i.e. those with standard hours greater than 30 or 35). Second, we evaluate the effect of a one hour reduction applied to workers who work more than 35 standard hours, assuming that the sample of individuals who can work overtime is composed by employees who work more than 30 hours. Third, following the examples of France and Germany, we calculate the substitution effect of a reduction of the working week to 35 hours.

For each policy experiment, we calculate the effects both under the assumption that the hourly wage does not change, and that the hourly wage adjusts to compensate for the loss in labour income due to reduction in the working hours. This last assumption amounts to assume a percentage increase in hourly wage equal to the percentage decrease in working hours ${ }^{17}$. Under this assumption we have to add the two effects. Since the sign of the coefficient of hourly wage is negative, as we have seen above, after the wage increase the income effect dominates, and the total effect in terms of new job lost would be smaller than in the case of constant hourly wage.

Table 4 presents the results of the first policy experiment.

Table 4

\footnotetext{
${ }^{16}$ Unfortunately, also with the panel at our disposal, we cannot employ more advanced policy evaluation methods, since no important measure on the matter has been adopted in the observation period.

${ }^{17}$ On the basis of the identity : $w_{0} H_{o}=w_{n} H_{o}$, where $w$ is the wage, $H$ are hours ad the subscripts $o$ and $n$ mean old and new respectively.
} 
A generalised reduction of one hour in the working week would generate a substitution effect ranging from a minimum value of $0.10 \%$ of new job lost over the total employment preceding the implementation of the policy and a maximum of $0.82 \%$ depending on the underlying assumptions on the individual behaviour. The gender difference is marked: the minimum value is $0.20 \%$ and the maximum $0.93 \%$ for men, and $0.05 \%$ and $0.56 \%$ for females.

\section{Table 5}

Table 5 shows that if the reduction of one hour is applied only to employees who work more than 35 hours per week the effect is smaller compared to the same assumption in Table 4. The wage effect helps to reduce the total effect: the underlying hypothesis is that it should increase by about $2.5 \%$ in order to keep the total labour income constant. The last experiment shows that a reduction to 35 hours has the biggest effect: the maximum loss in employment would amount to $3.5 \%$ and $1.91 \%$ under the assumption of independent unpaid overtime for men and women respectively (Table 6). The wage effect limits the loss, but a policy of constant labour income after the working time reduction would imply an increase of wages of around 15\% (considering the actual standard hours worked), an unrealistic policy option.

\section{Table 6}

How should we weight these effects in the current phase of employment growth? In year 2000 total employment in Italy has increased by $2 \%$. Let's make an extreme work-sharing assumption that the reduction in working hours is compensated by an equal increase of hours-equivalent workers (output constant with substitution from hours to workers, i.e. no scale effect, no substitution to capital, no efficiency gains, no increase in labour costs). In this case a reduction of one hour would imply an increase of employment ranging from $2.5 \%$ to $2.1 \%$ depending on the sampling assumption.

With this baseline comparison terms, our results suggest that the counter balancing overtime effect following a smooth reduction in the working week might be relatively minor. If, instead, actual hours fall a lot, like in the case of a reduction to 35 hours for all employees, work-sharing should become more effective. (Note that the same output constant assumption as in the case of a reduction of one hour would imply an absolutely unrealistic rise in employment ranging from 9 to $13 \%$ ). However, the substitution from standard hours to overtime is quite large, so that the implementation of this policy would require a careful evaluation of all the substitution and scale effects, not to talk about the necessary wage policy choices.

The conclusion of a minor impact on employment is reinforced if the percentage employment effect is calculated on the total employees in the labour market. If we believe that the workers excluded from our sample do not work overtime, the percentage effect on total employment (including part-time workers, temporary workers, the self-employed etc.) would be even smaller.

\footnotetext{
${ }^{18}$ Bank of Italy, yearly report of the Governor on 2001.
} 


\subsubsection{Other results}

The estimated coefficients of the control variables give other indications on the determinants of overtime work (see Tables A4.3-A4.5). These indications are coherent with the findings of the cited studies for other European countries. Paid overtime is less probable in small firms, in the public sector, among low educated workers, in the South of Italy, in families with more than one income earner. It is more probable among older workers, in the industrial sector, and among managers. The gender distinction reveals that married men are more likely to work overtime, whereas married women are less so. Males are more likely to work overtime in medium size firms (20 to 100 employees) compared to large or very small firms. Females, instead, are more likely to work overtime in large firms only (with more than 100 employees). Males of the North and Centre of Italy have a higher probability to work overtime than males working in the South; for females we observe only a significative coefficient of the dummy for the North East, an area that typically shows the highest employment rate of the country. In that area females have a probability to work overtime of 14 percentage points more than in the rest of Italy.

\subsection{The panel data analysis}

In order to establish if the cross-section analysis suffers from unobserved heterogeneity bias, we exploit the panel sub-sample of the Bank of Italy survey to estimate a panel data version of the probability model allowing for unobserved fixed effects that may be correlated with the probability of working overtime. Despite the presence of numerous control variables, the use of cross-section data runs the risk of omitted variables bias in the estimated coefficients. Our interest is in estimating the parameters of the time varying variables, in particular HWAGE and HSTAN. An appropriate technique in this situation is the conditional logistic functional form (Chamberlain, 1980) ${ }^{19}$. The results, however, will not be directly comparable with those obtained with the cross-section, for many reasons. One reason is that the sample on which the model can be estimated includes only the individuals who, over the observation period, changed status, i.e. from not working overtime to working overtime or vice-versa. We aimed, instead at an average measure of the weight of overtime work that takes also account of the behaviour of those who always work or never work overtime. Our main reason for using panel data, then, is simply to verify the unbiasedness of the cross-section results, mainly in terms of signs and significance of the estimated coefficients, once the unobserved fixed effects are taken account for.

After the selection, the sample for the three years panel $\left(1995,1998,2000^{20}\right)$ amounts to about 2500 observations. The descriptive statistics (see Table A5.1) show that the average values of the variables are very similar to those of the crosssection (presented in table A41): the probability of working overtime is around $35 \%$ for men and around $20 \%$ for women; men who work overtime, work nearly 4.5 hours more than the standard hours, and women a bit more than 3 hours.

Since the scope of this exercise is not a direct comparison with the measures derived in the preceding sections, for the estimation we do not select individuals

19 The coefficients of the time invariant variables (like sex) cannot be estimated with this technique; this is not a worry since this controls are of no real interest to us (and as far as sex is concerned, we estimate the model by gender anyway).

${ }^{20}$ We also conducted the same analysis on the 1993, 1995, 1998 panel: the results do not differ substantially. 
on the basis of standard hours in order not to loose observations ${ }^{21}$. The number of observations for males who changed status is 1149 (corresponding to 396 individuals) and for females is 322 (corresponding to 113 individuals). Table 7 reports the coefficients, standard errors and $z$ statistics of HSTAN and HWAGE for the whole sample and by gender. The signs, the significance level and the relative size of the coefficients are confirmed. The maximum estimated impact of the variable HSTAN in the logit functional form is 7 percentage points on average, 9 for men and 3.8 for women; and for HWAGE is 4 percentage points on average, 4.7 for men, 3.9 for women. The size of these impacts is different from those derived with the cross-section probit for the reasons explained above.

We therefore conclude that the cross-section results do not suffer from a big heterogeneity problem and may be used as evidence on the approximate range of variation of overtime hours.

Table 7 here

\section{Conclusions}

Critics of working hour reduction policies seem to agree that a reduction in working hours could bring about an increase in overtime work, thus limiting the creation of new jobs. We have sought to make some contribution to this debate by means of an empirical analysis on overtime work in Italy.

The data we have presented show overtime work to be a permanent feature of the Italian labour market. We set the study of overtime in a more general context compared to the majority of the other studies, extending the analysis to female workers and all sectors where overtime work is regularly observed. The data show that female overtime work has always been lower and less variable with respect to males'. During upswings firms resort to male overtime work first, and only afterwards to females' when the positive trend has consolidated, in such a way that the gender gap in overtime works tends to decrease near the peaks of the economic cycle. The other important indication that has emerged is that the steady decline in the number of weekly total (inclusive of overtime) and standard hours observed between 1989 and 2000 is dragged by female workers.

Abandoning the male perspective in discussions about the use of overtime, therefore, makes the argument that reducing working hours would lead to a widespread increase in overtime work, thus neutralising the beneficial effects on the number of employed people, less credible.

As far as overtime compensation is concerned, a distinguishing feature of the Italian system is that overtime hours involve lower costs than do normal hours. This is one of the reasons why companies have often chosen to respond to substantial market pressures by massive use of overtime work. In so doing, some of them have limited hiring of labour and worked understaffed for long stretches.

Our main question was: what impact would a reduction in working hours have on overtime work and how much the latter would become a substitute of new jobs? The tobit and probit econometric analysis of cross-section data has shown the existence of an inverse relation between standard hours of work, hourly wages and

\footnotetext{
${ }^{21}$ We estimated the model on individuals who worked over 30 standard hours as well: the results do not change. Moreover, because of differences in the historical archive with respect to the crosssection for the year 2000, we are not able to discard teachers from the sample. They are lumped together with white collar workers.
} 
overtime hours. This relation has proved to be robust to panel data analysis (we have estimated a conditional fixed effects logit model).

The estimated coefficients have allowed us to perform some simple policy experiments. A reduction of one hour applied to all employees working at least 30 or 35 hours would produce a negative effect on employment ranging from $-0.05 \%$ to $-0.56 \%$ for women and from $-0.20 \%$ to $-0.93 \%$ for men (the average ranges from $-0.15 \%$ to $-0.82 \%$ ) depending on different behavioural assumptions. These effects might be compared with those deriving from an extreme work-sharing assumption, where all lost hours are transformed in new jobs. In this case the employment growth would range from $2.1 \%$ to $2.5 \%$. A reduction to 35 hours would, of course, produce much bigger effects on the use of overtime, but presumably, on work-sharing too. For men these effects would range from $1.34 \%$ to $-3.35 \%$, whereas for women from $-0.25 \%$ to $-1.91 \%$ (the extreme worksharing assumption to compare with yields in this case the unrealistic figure of 9$15 \%$ employment growth).

Allowing also for the wage effect (i.e. of a positive increase in wages to compensate the reduction in hours) all the impacts just reported become lower because of the prevailing positive contribution of the income effect.

How should we view these effects in the current phase of employment growth?

In year 2000 total employment in Italy has increased by $2 \%$. The EU target is to reach the $70 \%$ employment rate by 2010 in all member countries. Given that the Italian employment rate in 2001 was $54.5 \%$, this means that the employment rate should increase on average by 1.71 percentage points per year, which implies a growth of $3.1 \%$ per year of the employment rate. With this baseline comparison terms, our results suggest that the counter balancing overtime effect following a smooth reduction (starting with one hour) in the working week might be relatively minor. This policy, even if the GDP grows slowly, would allow to meet the EU target.

A 35 hours policy, instead, given the current still quite high average number of weekly hours worked in Italy (due also to the relatively low female participation rate) seems to be less viable.

Two more points are worth stressing. Firstly, these employment effects of overtime work were calculated taking at the denominator the employees of our sample. The percentage effects on total employment (including part-time workers, temporary workers, etc.) would then be even smaller. Secondly, and more importantly, in evaluating these effects we have to give more weight to female employment. In Italy, 70\% of the growth in employment from 1996 to 2001 is due to female workers. Since the effect on female employment is a half on average that of males, the final job loss induced by a rise in overtime work following a reduction in working hours should not be viewed as an obstacle to the implementation of this policy. 


\section{References}

Bank of Italy (2002), "Yearly Report of the Governor on 2001”, Rome.

Bank of Italy (2000), "I bilanci delle famiglie italiane nell'anno 2000", Banca d'Italia, Centro Stampa.

Bank of Italy (2000), "Supplemento al Bollettino Statistico. Note metodologiche e informazioni statistiche”, Banca d'Italia, Centro Stampa.

Bauer T. and K.T. Zimmermann (1999), "Overtime work and overtime compensation in Germany IZA discussion paper No. 48.

Bell, D.N.F. and R.A. Hart (1999), "Overtime working in an unregulated labor market", IZA discussion paper No 44.

Calmfors L. (1985), "Work Sharing, Employment and Wages", European Economic Review (27), pp. 293-309.

Calmfors L. and M. Hoel (1988), "Worksharing and overtime", Scandinavian Journal of Economics, 90 (1), 45-52.

Calmfors L. and M. Hoel (1989), "Work Sharing, Employment and Shiftwork", Oxford Economic Papers, no. 41, pp. 758-773.

Chamberlain G. (1980), “Analysis of Covariance with Qualitative Data”, Review of Economic Studies, Vol. 47, pp. 225-38.

Crepon B. and F. Kramarz, "Employed 40 Hours or Not-Employed 39: Lessons from the 1982 Mandatory Reduction of the Workweek", IZA discussion paper No. 416, January.

Ehrenberg R.G. (1971), "Heterogeneous Labor, the Internal Labor Market and the Dynamics of Employment-Hours Decisions", Journal of Economic Theory, 3, 85104.

Frederiksen A., Graversen E. K., Smith N. (2001), "Overtime work, dual job holding and taxation", IZA discussion paper No. 323.

Gregory M. e A.S. Kalwij (2000), "Overtime hours in Great Britain over the period 1975-1999: A Panel Data Analysis”, IZA discussion paper No. 153, May .

Hart R.A. (1987), “Working Time and Employment”, Allen \& Unwin, Boston.

Hart R.A. e R.J. Ruffell (1992), "The cost of overtime hours in British production industries", Economica (60), pp. 183-201.

Hart R.A. e Yue Ma (2000), "Why do firms pay an overtime premium?", IZA discussion paper No. 163 
Hunt, J. (1996), "The response of wages and actual hours worked to the reduction of standard hours in Germany", CEPR discussion paper, no. 1526, Centre for Economic Policy Research.

Hunt, J. (1999), "Has work sharing worked in Germany?", Quarterly Journal of Economics, February, pp.117-148.

Pannenberg M., Wagner G.G. (2001), "Why do overtime work, overtime compensation and the distribution of economic well-being. Evidence for the West Germany and Great Britain IZA discussion paper No. 318.

Trejo S.J. (1991), "The Effects of Overtime Pay regulation on Worker Compensation", The American Economic Review, vol. 81, no. 4, pp.719-740.

Trejo S.J. (1993), "Overtime Pay, Overtime Hours, and Labor Unions", Journal of Labor Economics, vol. 11, no. 2, pp. 253-278.

Trejo S.J. (2001), "Does the statutory overtime premium discourage long workweeks?", IZA discussion paper No. 373. 
Fig. 1

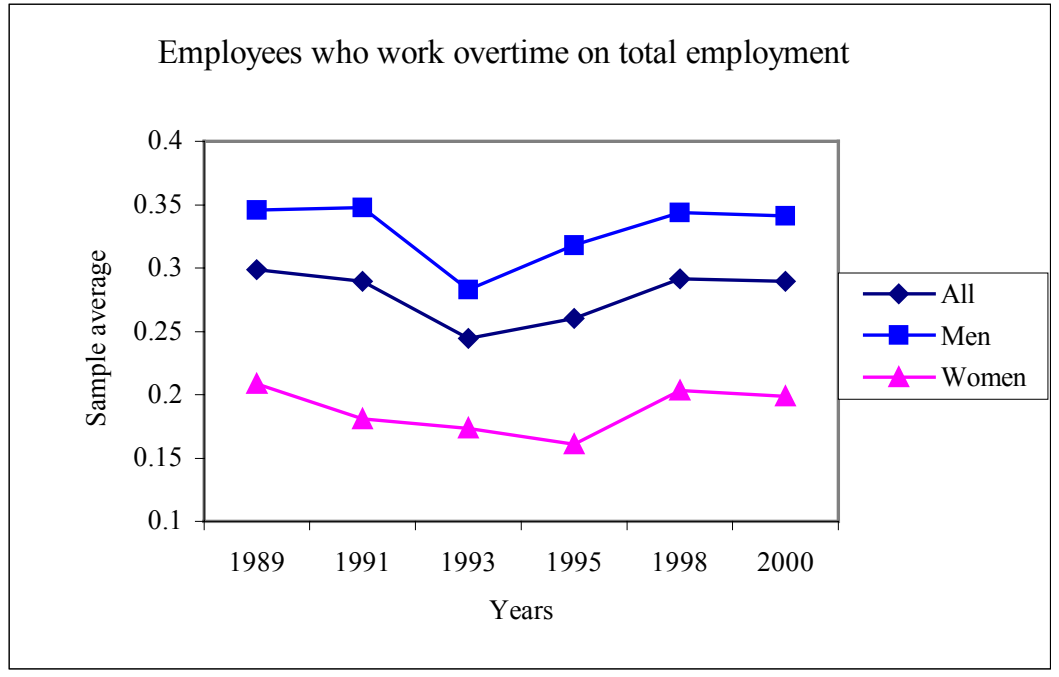

Source: Bank of Italy

Fig. 2

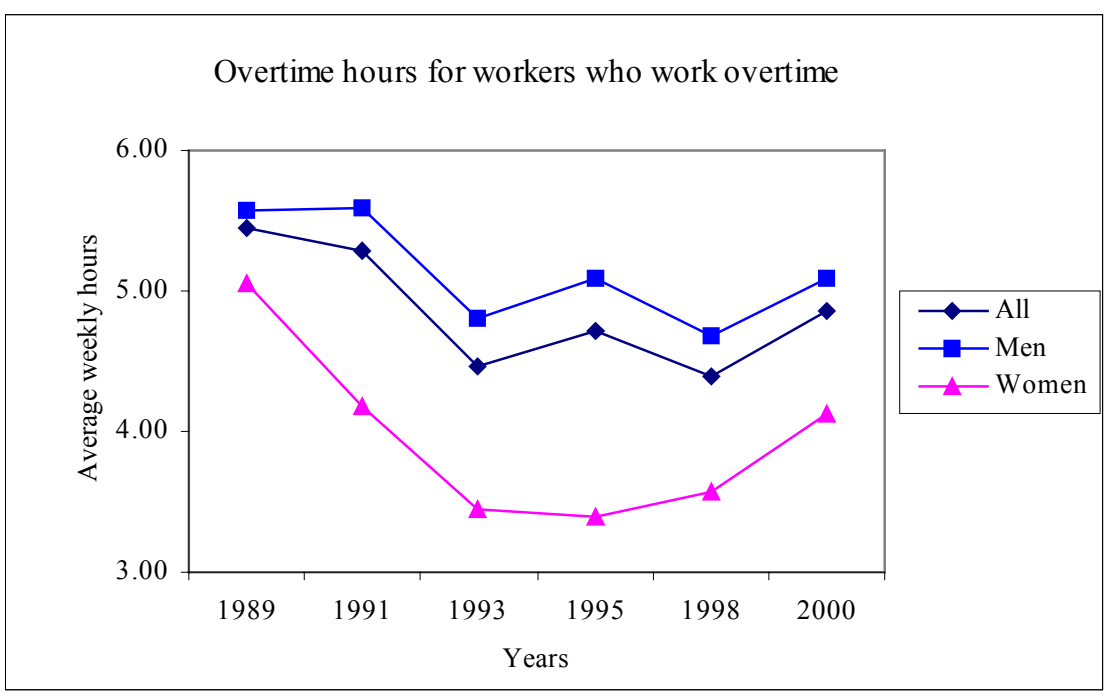

Source: Bank of Italy 
Fig. 3

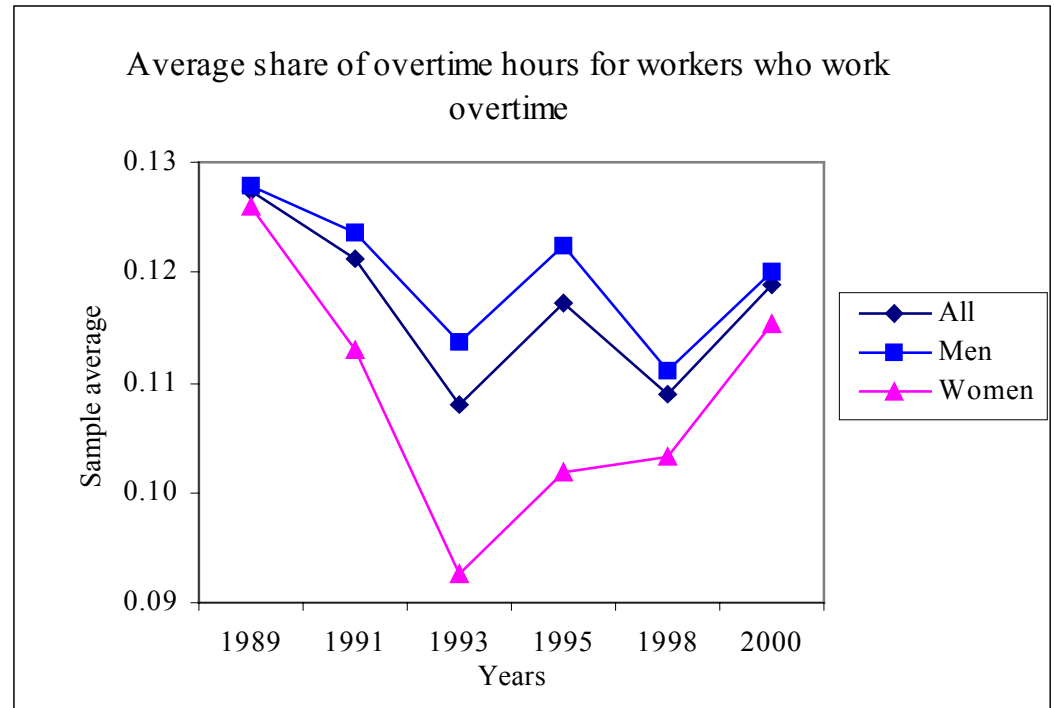

Source: Bank of Italy

Fig. 4

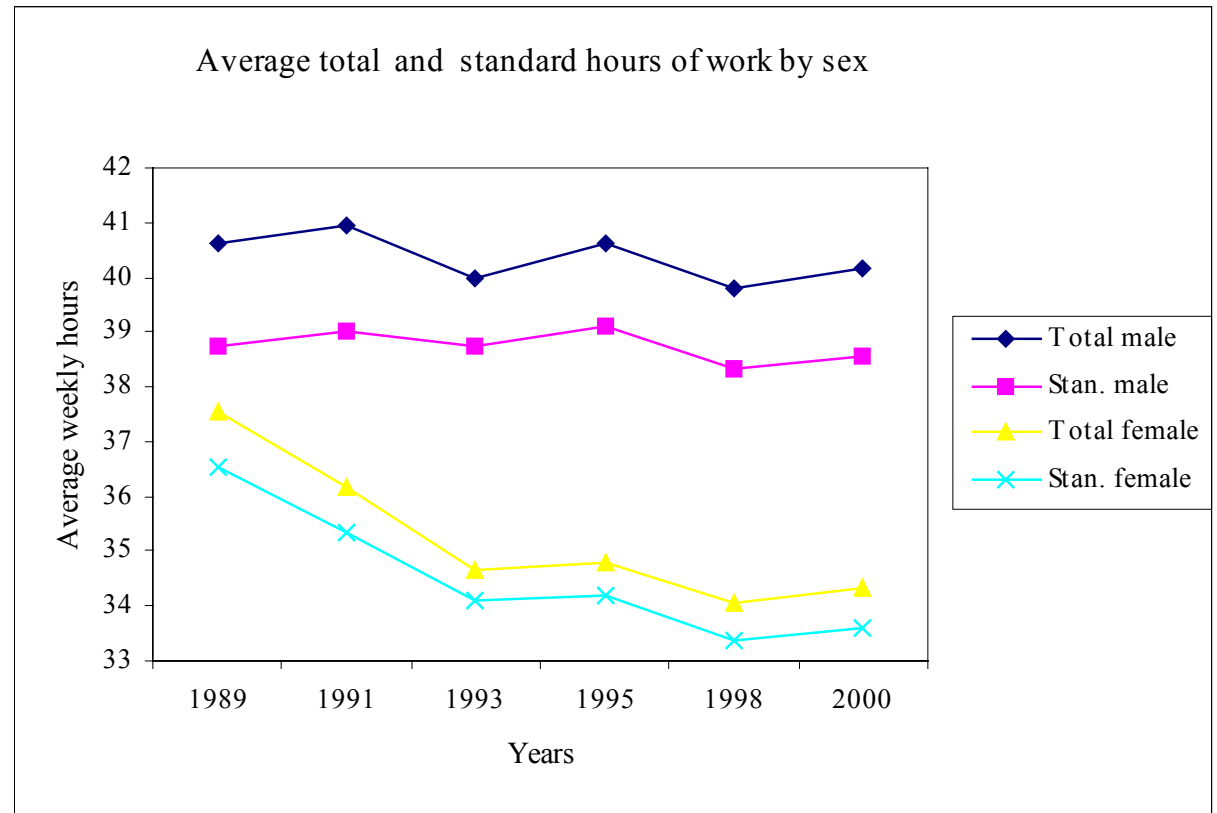

Source: Bank of Italy 
Table 1 HOURLY COST OF LABOUR OF A BLUE COLLAR WORKER

\begin{tabular}{|c|c|c|c|}
\hline Earnings components & & vertime & \\
\hline (Euro per hour) & $+25 \%$ & $+50 \%$ & \\
\hline & (of & direct earnings) & \\
\hline Direct earnings & & & \\
\hline Contractual minimum & 2.59 & 2.59 & 2.59 \\
\hline Piece rate contractual minimum & 0.09 & 0.09 & 0.09 \\
\hline Productivity bonus & 0.02 & & \\
\hline Seniority increases & 0.26 & & \\
\hline Cost of living bonus & 2.98 & 2.98 & 2.98 \\
\hline DEE* & 0.06 & 0.06 & 0.06 \\
\hline Total direct earnings & 5.99 & 7.49 & 8.99 \\
\hline Indirect earnings & & & \\
\hline Union meetings & 0.03 & & \\
\hline Study bonus & 0.03 & & \\
\hline Holidays with pay & 0.26 & & \\
\hline Former days of holidays & 0.05 & & \\
\hline Paid permit & 0.11 & & \\
\hline Hours fo work reductions & 0.25 & & \\
\hline Vacations & 0.56 & & \\
\hline Extra monthly pay & 0.60 & & \\
\hline Seniority increases & 0.09 & & \\
\hline End of job bonus & 1.72 & & \\
\hline Total indirect earnings & 3.69 & & \\
\hline Social allowances & 3.55 & 3.18 & 3.82 \\
\hline Total cost of labour & 13.24 & 10.67 & 12.81 \\
\hline
\end{tabular}

Source: Fiom ( May 1997)

*Distinct Element of Earnings:this is an extra part of the contractual minimum that is subtracted from the base contractual wage when computing the extra components of pay that are calculated as percentages of the base contractual wage. 
ALL

a

$\mathrm{b}^{* *} \quad \mathrm{c} * * *$

HSTAN HSTAN1 HDIF40 HWAGE^ ${ }^{\wedge}$ N. obs. Predicted p.

Sample selections:

Standard hours $>30$

Standard hours $>35$

Standard hours $>30$

Standard hours $>35$

Standard hours $>30$

Standard hours $>35$

Standard hours $>30$

Standard hours $>35$

Standard hours $>30$

Standard hours $>35$

Standard hours $>30$

Standard hours $>35$

$\begin{array}{cccccc}-0.0375 & & & -0.0105 & 4234 & 0.258 \\ -0.0164 & & & -0.0101 & 3754 & 0.205 \\ & -0.0864 & -0.0085 & -0.0121 & 4234 & 0.263 \\ & -0.0425 & -0.0095 & -0.0104 & 3754 & 0.205 \\ & & & & & \end{array}$

$\begin{array}{rrrrrr}-0.0421 & & & -0.0128 & 2893 & 0.300 \\ -0.0215 & & & -0.0121 & 2557 & 0.246 \\ & -0.0987 & -0.0110 & -0.0146 & 2893 & 0.314 \\ & -0.0591 & -0.0116 & -0.0123 & 2557 & 0.246\end{array}$

\section{WOMEN}

$\begin{array}{rrrrr}-0.0238 & & -0.0065 & 1341 & 0.176 \\ -0.0059 & & -0.0076 & 1197 & 0.127 \\ & -0.0604-0.0018 \mathrm{~ns} & -0.0084 & 1341 & 0.169 \\ & -0.0158-0.0036 \mathrm{~ns} & -0.0082 & 1197 & 0.126\end{array}$

*All effects are significant at the 1\% significance level except were ns (not significant) is specified (in col.c).

$* *(=a$ if $\mathrm{a}<=40 ;=40$ if $\mathrm{a}>40)$

$* * * a-40$ if $\mathrm{a}>40$

$\wedge$ Per 1000 old It. Liras (approx. 1/2 Euro)

Data are weighted. Robust standard errors. 
Table 3 MARGINAL EFFECTS OF STANDARD HOURS

AND HOURLY WAGE ON OVERTIME HOURS

(Tobit model - Unconditional expected values*)

ALL

$\begin{array}{ccccr}\mathrm{a} & \mathrm{b}^{* *} & \mathrm{c}^{* * *} & \mathrm{~d} & \mathrm{e} \\ \text { HSTAN } & \text { HSTAN1 } & \text { HDIF40 } & \text { HWAGE }^{\wedge} & \text { N. obs. }\end{array}$

Sample selections:

Standard hours $>30$

Standard hours $>35$

Standard hours $>30$

Standard hours $>35$

Standard hours $>30$

Standard hours $>35$

Standard hours $>30$

Standard hours $>35$

Standard hours $>35$

Standard hours $>30$

Standard hours $>35$
$-0.1605$

$-0.0701$

-0.3243
-0.1705
MEN

$-0.1878$

$-0.0966$

$-0.3680$

$-0.2305$

-0.0421
-0.0435

$-0.0655$

$-0.0607$

4234

$-0.0699$

$-0.0617$

4234

3754

\section{WOMEN}

$$
\begin{aligned}
& -0.1018 \\
& -0.0232
\end{aligned}
$$

$-0.0399$

$-0.0387$

$-0.0442$

$-0.0421$

1341

1197

$-0.2238-0.0056 \mathrm{~ns}$

1341

$-0.0808-0.0099$ ns

*All effects are significant at the $1 \%$ significance level except were ns (not significant) is $* *(=a$ if $\mathrm{a}<=40 ;=40$ if $\mathrm{a}>40)$

$* * * a-40$ if $\mathrm{a}>40$

$\wedge$ Per 1000 old It. Liras (approx. 1/2 Euro)

$\wedge \wedge$ N. of potential new workers substituted with overtime work: 1$)\left(a^{*} \mathrm{e}\right) /$ average sample $\wedge \wedge \wedge \mathrm{f} / \mathrm{e}$ 
Table 4 POLICY EXPERIMENTS: GENERALIZED REDUCTION OF ONE HOUR (\% employment effects)

Substitution eff. Subst+Wage eff.

Sample selections:

ALL

$\begin{array}{lll}\text { Standard hours }>30 & -0.39 \% & -0.33 \% \\ \text { Standard hours }>35 & -0.15 \% & -0.10 \% \\ \text { Standard hours }>30 & -0.82 \% & -0.75 \% \\ \text { Standard hours }>35 & -0.38 \% & -0.33 \%\end{array}$

MALES

$\begin{array}{lll}\text { Standard hours }>30 & -0.46 \% & -0.38 \%\end{array}$

Standard hours $>35 \quad-0.20 \% \quad-0.15 \%$

$\begin{array}{lll}\text { Standard hours }>30 & -0.93 \% & -0.66 \%\end{array}$

Standard hours $>35 \quad-0.51 \% \quad-0.45 \%$

\section{FEMALES}

$\begin{array}{lll}\text { Standard hours }>30 & -0.25 \% & -0.22 \% \\ \text { Standard hours }>35 & -0.05 \% & -0.02 \% \\ \text { Standard hours }>30 & -0.56 \% & -0.52 \% \\ \text { Standard hours }>35 & -0.18 \% & -0.15 \%\end{array}$


Table 5 REDUCTION OF ONE HOUR

APPLIED ONLY TO WORKERS WHO WORK MORE THAN 35 STANDARD HOURS

(\% employment effects)

Substitution eff. Subst+Wage eff.

Sample selection: standard hours $>30$

ALL

$\begin{array}{ccc}-0.34 \% & & -0.29 \% \\ -0.71 \% & & -0.66 \% \\ & \text { MALES } & \\ -0.39 \% & & -0.33 \% \\ -0.81 \% & & -0.74 \% \\ & \text { FEMALES } & \\ -0.22 \% & & -0.19 \% \\ -0.49 \% & & -0.46 \%\end{array}$

Table 6 POLICY EXPERIMENTS: REDUCTION TO 35 HOURS (\% employment effects)

Substitution e Subst+Wage eff.

Sample selections:

Standard hours $>30$

$-2.08 \%$

$-0.91 \%$

Standard hours $>35$

$-2.98 \%$

Standard hours $>30$

$-1.57 \%$

ALL

Standard hours $>35$

$-1.57 \%$

Standard hours $>30$

$-2.62 \%$

Standard hours $>35$

$-1.34 \%$

Standard hours $>30$

$-3.50 \%$

Standard hours $>35$

$-2.19 \%$

$-1.75 \%$

$-0.61 \%$

$-2.73 \%$

$-1.35 \%$

MALES

$-2.17 \%$

$-0.93 \%$

$-3.17 \%$

$-1.91 \%$

Standard hours $>30$

$-1.11 \%$

FEMALES

Standard hours $>35$

$-0.25 \%$

$-0.95 \%$

Standard hours $>30$

$-1.91 \%$

$-0.10 \%$

Standard hours $>35$

$-0.69 \%$

$-1.77 \%$

$-0.56 \%$ 


\begin{tabular}{|c|c|c|c|c|c|c|c|c|}
\hline HWAGE & -0.172 & 0.024 & -7.2 & -0.189 & 0.028 & -6.7 & -0.156 & 0.056 \\
\hline HSTAN & -0.298 & 0.028 & -10.6 & -0.350 & 0.038 & -9.3 & -0.223 & 0.046 \\
\hline AGE & 0.510 & 0.148 & 3.5 & 0.672 & 0.179 & 3.8 & 0.036 & 0.299 \\
\hline AGE2 & -0.005 & 0.002 & -3.0 & -0.007 & 0.002 & -3.4 & 0.000 & 0.004 \\
\hline N. obs & 1149 & & & 825 & & & 322 & \\
\hline N. of groups & 396 & & & 283 & & & 113 & \\
\hline Avg. Obs. & 2.9 & & & 2.9 & & & 2.8 & \\
\hline LR chi2(16) & 223.3 & & & 185.93 & & & 53.54 & \\
\hline Logl-1 it. 0 & -404.3 & & & -284.9 & & & -113.56 & \\
\hline Logl-1 it. 5 & -307.6 & & & -208.2 & & & -90.48 & \\
\hline
\end{tabular}




\section{Appendix 1 - Overtime regulation in Italy}

The basic regulation of working hours goes back to R.D.L. $N^{\circ} 692$ of 15 March 1923 introducing the maximum of 8 hours per day and 48 hours per week "wherever wage or salary labour in the employ or under the direct control of others is given" (Art. 1, comma 1). This 1923 decree provides for the extension of the normal working day. Article 5 regulates recourse to overtime specifying that consensual extensions to working hours are authorised, remunerated with an increase of not less than $10 \%$, provided no more than 2 hours per day and 12 hours per week are worked, thus capping weekly work at 60 hours.

The legal provisions on working hours went unchanged for many years; at the same time, in contrast to this state of paralysis, trade union activity became intense. In the years between 1962 and 1972 Italian metal-workers unions, in the renewal of three successive national collective-labour contracts, reached agreement on a progressive reduction in the working week from 48 to 40 hours.

The aim of reducing the ambit of overtime work to "free up", at least in theory, some job slots is at the root of the new regulation dealing with contributions for overtime work introduced by Law 549 (art. 2) of 20 December 1995.

The issue of working hours was recently updated by Law 196 of 24 June 1997. This law expressly states "normal working hours shall be 40 hours per week" and in so doing limits itself to acknowledging what has already long been common company practice.

In Decree Law. 335 of 29 September 1998, under "Urgent instructions in dealing with overtime work", we see yet another amendment to the law on overtime. The decree partially incorporates what was already agreed with the trade unions on the matter in the Interconfederal agreement of 12 November $1997^{22}$. This decree, itself substantially amended by Law 409 of 27 November 1988, has completely taken over from Article 5 (A) of Royal Decree 692/1923, introduced by Law 1079 of 30 October 1955.

The new regulation provides For a maximum period of overtime that may not, in the absence of a collective contract, exceed 250 hours per year and 80 hours each quarter.

In considering the legal aspects of overtime, we have hitherto referred exclusively to Italian legislation. However, major sway in regulating the issue is held by collective contracts. Ministry of Labour ministerial circular $\mathrm{N}^{\circ} 10 / 99$ states that the limits in overtime laid down by law - contained in a "period not exceeding 250 hours per year and 80 hours per trimester" (Art 5 bis, comma 2) - "are valid exclusively where no collective contract has been concluded".

The law is to be applied "exclusively" as a supplementary measure, that is to say in situations where a collective contract defining the issue is absent.

\footnotetext{
${ }^{22}$ See Collective Notice 12 November 1997 between CONFINDUSTRIA and CGIL,CISL,UIL. Collective notice regarding incorporation of Directive 93/104/ECJ re working hours.
} 


\section{Appendix 2}

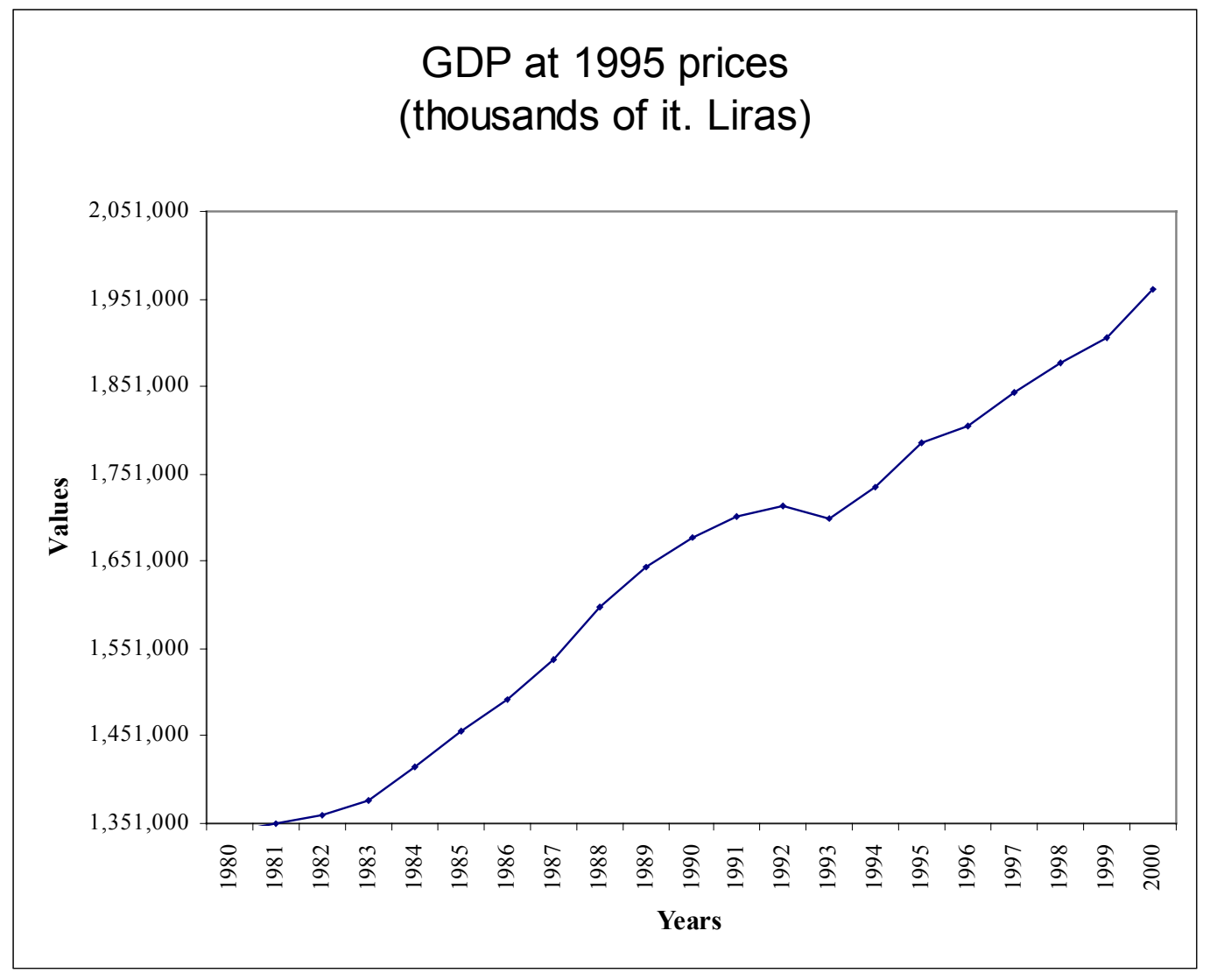




\section{Appendix 3 - Sample selection}

We had to select people who have the chance to work overtime. We first excluded self-employed workers.

We then could follow two strategies:

1) Check the professional position of employees who work overtime. Then include in the sample all those professional positions that were represented in the sample of employees who had worked overtime. All professional positions considered in the survey were represented, indicating that no one should a priori be excluded. We fixed a criteria: if the percentage of employees who did work overtime on the total number of employees of that professional position was exceptionally small, that would indicate special regulations that limit the use of overtime. On this basis, we excluded only one group, i.e. all teachers of any kind of school.

2) We could also choose another strategy. Use question 4 in the questionnaire:

"In 2000 did you have the chance to do paid overtime?"

If yes, the interviewed should respond the subsequent question 5 :

"How many hours did you work overtime on average per week?"

Some responded zero; they had the possibility, but they did not take this chance.

In fact: ORESTRA (hours of overtime work) contains 2041 valid observations.

Only 1641 are greater than 0 .

We experimented both strategies. Applying the second strategy, we obtained meaningless results that contradicted well established stylized facts (like the fact that, for example, overtime paid work is more common in the North than in the South of Italy).

This is because question 4 was badly posed for our scopes. In fact, one could answer "no" for personal reasons, not for contract clauses.

So we decided to choose strategy 1), since it proved to give sensible results on the facts of overtime work that are common knowledge. 
Table A4.1 - DESCRIPTIVE STATISTICS OF THE CROSS SECTION

(employees who worked more than 30 hours per week)

\begin{tabular}{|c|c|c|c|c|c|c|c|c|}
\hline \multirow[b]{2}{*}{ Variable } & \multicolumn{4}{|c|}{$\begin{array}{c}\text { Males } \\
(34 \% \text { worked overtime })\end{array}$} & \multicolumn{4}{|c|}{$\begin{array}{c}\text { Females } \\
(20 \% \text { worked overtime })\end{array}$} \\
\hline & Mean & S.D. & Mean & S.D. & Mean & S.D. & Mean & S.D. \\
\hline N. of overtime hours & 0 & 0 & 4.54 & 3.74 & 0 & 0 & 3.51 & 2.70 \\
\hline Standard hours (HSTAN) & 41.2 & 5.9 & 37.8 & 3.9 & 39.5 & 4.5 & 37.2 & 4.4 \\
\hline Hourly wage (HWAGE) & 14.02 & 7.07 & 14.01 & 4.58 & 12.30 & 4.44 & 12.81 & 3.79 \\
\hline Age & 39.56 & 10.52 & 40.10 & 9.42 & 37.75 & 9.91 & 37.07 & 8.76 \\
\hline N. of income earners & 2.06 & 0.91 & 2.02 & 0.92 & 2.37 & 0.83 & 2.17 & 0.84 \\
\hline Married & 0.66 & 0.47 & 0.70 & 0.46 & 0.60 & 0.49 & 0.59 & 0.49 \\
\hline $19<$ n. of employees in the firm $<50$ & 0.13 & 0.33 & 0.17 & 0.37 & 0.12 & 0.33 & 0.13 & 0.33 \\
\hline $49<$ n. of employees in the firm $<100$ & 0.09 & 0.29 & 0.16 & 0.37 & 0.11 & 0.32 & 0.10 & 0.30 \\
\hline $99<$ n. of employees in the firm $<500$ & 0.13 & 0.33 & 0.14 & 0.35 & 0.09 & 0.29 & 0.14 & 0.35 \\
\hline $499<$ n. of employees in the firm & 0.14 & 0.34 & 0.15 & 0.36 & 0.08 & 0.28 & 0.17 & 0.38 \\
\hline Public sector firm & 0.22 & 0.42 & 0.18 & 0.39 & 0.28 & 0.45 & 0.21 & 0.41 \\
\hline Elementary school diploma & 0.10 & 0.30 & 0.08 & 0.27 & 0.06 & 0.24 & 0.02 & 0.16 \\
\hline Middle school diploma & 0.38 & 0.49 & 0.39 & 0.49 & 0.30 & 0.46 & 0.23 & 0.42 \\
\hline High school diploma (3-4 years) & 0.10 & 0.30 & 0.12 & 0.33 & 0.13 & 0.33 & 0.15 & 0.36 \\
\hline High school diploma ( 5 years) & 0.33 & 0.47 & 0.33 & 0.47 & 0.41 & 0.49 & 0.49 & 0.50 \\
\hline Industrial sector & 0.38 & 0.49 & 0.49 & 0.50 & 0.28 & 0.45 & 0.29 & 0.45 \\
\hline Construction sector & 0.08 & 0.27 & 0.05 & 0.21 & 0.02 & 0.13 & 0.01 & 0.09 \\
\hline White collar - low level & 0.34 & 0.47 & 0.34 & 0.47 & 0.54 & 0.50 & 0.59 & 0.49 \\
\hline White collar - high level & 0.09 & 0.29 & 0.08 & 0.27 & 0.08 & 0.26 & 0.09 & 0.28 \\
\hline Manager & 0.05 & 0.21 & 0.03 & 0.16 & 0.02 & 0.15 & 0.02 & 0.13 \\
\hline Living in the North West & 0.31 & 0.46 & 0.29 & 0.45 & 0.40 & 0.49 & 0.30 & 0.46 \\
\hline Living in the North East & 0.17 & 0.38 & 0.31 & 0.46 & 0.21 & 0.41 & 0.36 & 0.48 \\
\hline Living in the Centre & 0.21 & 0.41 & 0.26 & 0.44 & 0.23 & 0.42 & 0.24 & 0.43 \\
\hline N. of obs. & 1933 & & 964 & & 1079 & & 262 & \\
\hline
\end{tabular}




\begin{tabular}{|c|c|c|c|c|c|c|}
\hline \multirow[b]{3}{*}{ HWAGE } & \multicolumn{3}{|c|}{ PROBIT } & \multicolumn{3}{|c|}{ TOBIT } \\
\hline & Coef. & Std. Err & $\mathrm{z}$ & \multicolumn{2}{|c|}{ Coef. Std. Err. } & \multirow{2}{*}{$\begin{array}{c}z \\
-6.4\end{array}$} \\
\hline & -0.033 & 0.006 & -5.1 & -0.236 & 0.037 & \\
\hline HSTAN & -0.116 & 0.006 & -18.3 & -0.579 & 0.037 & -15.6 \\
\hline Sex & 0.579 & 0.052 & 11.1 & 3.726 & 0.315 & 11.8 \\
\hline Age & 0.080 & 0.018 & 4.5 & 0.512 & 0.106 & 4.8 \\
\hline Age sq. & -0.001 & 0.000 & -4.2 & -0.006 & 0.001 & -5.0 \\
\hline N. of income earners & -0.095 & 0.027 & -3.5 & -0.505 & 0.155 & -3.3 \\
\hline Married & 0.039 & 0.056 & 0.7 & 0.567 & 0.319 & 1.8 \\
\hline $19<$ n. of employees in the firm $<50$ & 0.157 & 0.073 & 2.1 & 0.888 & 0.423 & 2.1 \\
\hline $49<$ n. of employees in the firm $<100$ & 0.241 & 0.079 & 3.1 & 1.080 & 0.453 & 2.4 \\
\hline $99<$ n. of employees in the firm $<500$ & 0.159 & 0.078 & 2.0 & 0.996 & 0.452 & 2.2 \\
\hline $499<$ n. of employees in the firm & 0.237 & 0.079 & 3.0 & 1.362 & 0.453 & 3.0 \\
\hline Public sector firm & -0.187 & 0.077 & -2.4 & -1.011 & 0.451 & -2.2 \\
\hline Elementary school diploma & -0.309 & 0.134 & -2.3 & -1.407 & 0.772 & -1.8 \\
\hline Middle school diploma & -0.161 & 0.101 & -1.6 & -0.538 & 0.581 & -0.9 \\
\hline High school diploma (3-4 years) & -0.089 & 0.109 & -0.8 & -0.301 & 0.633 & -0.5 \\
\hline High school diploma (5 years) & -0.028 & 0.089 & -0.3 & -0.291 & 0.513 & -0.6 \\
\hline Industrial sector & 0.144 & 0.054 & 2.7 & 0.454 & 0.316 & 1.4 \\
\hline Construction sector & -0.206 & 0.112 & -1.8 & -0.625 & 0.644 & -1.0 \\
\hline White collar - low level & -0.007 & 0.063 & -0.1 & 0.127 & 0.368 & 0.4 \\
\hline White collar - high level & 0.045 & 0.103 & 0.4 & 0.736 & 0.604 & 1.2 \\
\hline Manager & 0.337 & 0.166 & 2.0 & 2.738 & 0.946 & 2.9 \\
\hline Living in the North West & 0.296 & 0.068 & 4.4 & 3.089 & 0.403 & 7.7 \\
\hline Living in the North East & 0.740 & 0.071 & 10.4 & 4.536 & 0.420 & 10.8 \\
\hline Living in the Centre & 0.406 & 0.070 & 5.8 & 2.158 & 0.419 & 5.2 \\
\hline _cons & 2.173 & 0.452 & 4.8 & 8.446 & 2.660 & 3.2 \\
\hline N. obs. & 4234 & & & & & \\
\hline of which censored & & & & 1225 & & \\
\hline of which uncens. & & & & 3009 & & \\
\hline Pseudo R2 & 0.15 & & & 0.06 & & \\
\hline
\end{tabular}




\begin{tabular}{|c|c|c|c|c|c|c|}
\hline & \multicolumn{3}{|c|}{ PROBIT } & \multicolumn{3}{|c|}{ TOBIT } \\
\hline & Coef. & Std. Err. & $\mathrm{z}$ & Coef. & Std. Err. & $\mathrm{z}$ \\
\hline HWAGE & -0.037 & 0.007 & -5.1 & -0.254 & 0.042 & -6.0 \\
\hline HSTAN & -0.121 & 0.008 & -16.1 & -0.585 & 0.043 & -13.5 \\
\hline Age & 0.093 & 0.021 & 4.4 & 0.593 & 0.125 & 4.8 \\
\hline Age sq. & -0.001 & 0.000 & -4.2 & -0.007 & 0.001 & -4.9 \\
\hline N. of income earners & -0.057 & 0.032 & -1.8 & -0.431 & 0.182 & -2.4 \\
\hline Married & 0.145 & 0.071 & 2.0 & 1.151 & 0.403 & 2.9 \\
\hline $19<$ n. of employees in the firm $<50$ & 0.186 & 0.087 & 2.1 & 1.041 & 0.499 & 2.1 \\
\hline $49<\mathrm{n}$. of employees in the firm $<100$ & 0.335 & 0.094 & 3.6 & 1.315 & 0.536 & 2.5 \\
\hline $99<\mathrm{n}$. of employees in the firm $<500$ & 0.087 & 0.093 & 0.9 & 0.817 & 0.537 & 1.5 \\
\hline $499<$ n. of employees in the firm & 0.148 & 0.094 & 1.6 & 0.835 & 0.541 & 1.6 \\
\hline Public sector firm & -0.120 & 0.097 & -1.2 & -0.559 & 0.562 & -1.0 \\
\hline Elementary school diploma & -0.379 & 0.156 & -2.4 & -1.254 & 0.898 & -1.4 \\
\hline Middle school diploma & -0.216 & 0.122 & -1.8 & -0.562 & 0.702 & -0.8 \\
\hline High school diploma (3-4 years) & -0.178 & 0.136 & -1.3 & -0.354 & 0.783 & -0.5 \\
\hline High school diploma ( 5 years) & -0.085 & 0.109 & -0.8 & -0.283 & 0.629 & -0.5 \\
\hline Industrial sector & 0.193 & 0.065 & 3.0 & 0.590 & 0.375 & 1.6 \\
\hline Construction sector & -0.178 & 0.119 & -1.5 & -0.514 & 0.696 & -0.7 \\
\hline White collar - low level & -0.063 & 0.078 & -0.8 & -0.102 & 0.447 & -0.2 \\
\hline White collar - high level & -0.068 & 0.123 & -0.6 & 0.147 & 0.718 & 0.2 \\
\hline Manager & 0.316 & 0.191 & 1.7 & 2.655 & 1.092 & 2.4 \\
\hline Living in the North West & 0.358 & 0.078 & 4.6 & 3.562 & 0.467 & 7.6 \\
\hline Living in the North East & 0.783 & 0.083 & 9.4 & 4.832 & 0.491 & 9.8 \\
\hline Living in the Centre & 0.454 & 0.081 & 5.6 & 2.286 & 0.483 & 4.7 \\
\hline _cons & 2.563 & 0.537 & 4.8 & 9.946 & 3.136 & 3.2 \\
\hline N. obs. & 2893 & & & & & \\
\hline of which censored & & & & 193 & & \\
\hline of which uncens. & & & & 96 & & \\
\hline Pseudo R2 & 0.16 & & & 0.0 & & \\
\hline
\end{tabular}




\begin{tabular}{|c|c|c|c|c|c|c|}
\hline & \multicolumn{3}{|c|}{ PROBIT } & \multicolumn{3}{|c|}{ TOBIT } \\
\hline & Coef. & Std. Err. & $\mathrm{z}$ & Coef. & Std. Err. & $\mathrm{z}$ \\
\hline HWAGE & -0.025 & 0.014 & -1.8 & -0.211 & 0.075 & -2.8 \\
\hline HSTAN & -0.092 & 0.012 & -7.7 & -0.539 & 0.068 & -7.9 \\
\hline Age & 0.066 & 0.038 & 1.7 & 0.415 & 0.208 & 2.0 \\
\hline Age sq. & -0.001 & 0.000 & -1.8 & -0.006 & 0.003 & -2.2 \\
\hline N. of income earners & -0.153 & 0.054 & -2.8 & -0.338 & 0.289 & -1.2 \\
\hline Married & -0.104 & 0.094 & -1.1 & -0.736 & 0.498 & -1.5 \\
\hline $19<\mathrm{n}$. of employees in the firm $<50$ & 0.111 & 0.141 & 0.8 & 0.494 & 0.760 & 0.7 \\
\hline $49<\mathrm{n}$. of employees in the firm $<100$ & 0.001 & 0.153 & 0.0 & 0.411 & 0.821 & 0.5 \\
\hline $99<\mathrm{n}$. of employees in the firm $<500$ & 0.407 & 0.147 & 2.8 & 1.594 & 0.790 & 2.0 \\
\hline $499<$ n. of employees in the firm & 0.540 & 0.151 & 3.6 & 2.924 & 0.793 & 3.7 \\
\hline Public sector firm & -0.255 & 0.131 & -2.0 & -1.638 & 0.719 & -2.3 \\
\hline Elementary school diploma & -0.295 & 0.301 & -1.0 & -3.553 & 1.669 & -2.1 \\
\hline Middle school diploma & -0.078 & 0.188 & -0.4 & -0.953 & 1.001 & -1.0 \\
\hline High school diploma (3-4 years) & 0.051 & 0.188 & 0.3 & -0.555 & 1.005 & -0.6 \\
\hline High school diploma ( 5 years) & 0.043 & 0.158 & 0.3 & -0.691 & 0.829 & -0.8 \\
\hline Industrial sector & 0.027 & 0.105 & 0.3 & 0.116 & 0.564 & 0.2 \\
\hline Construction sector & -0.466 & 0.411 & -1.1 & -2.234 & 2.170 & -1.0 \\
\hline White collar - low level & 0.112 & 0.119 & 0.9 & 0.511 & 0.643 & 0.8 \\
\hline White collar - high level & 0.321 & 0.200 & 1.6 & 2.161 & 1.068 & 2.0 \\
\hline Manager & 0.545 & 0.344 & 1.6 & 2.888 & 1.849 & 1.6 \\
\hline Living in the North West & 0.036 & 0.141 & 0.3 & 1.541 & 0.778 & 2.0 \\
\hline Living in the North East & 0.500 & 0.144 & 3.5 & 3.127 & 0.787 & 4.0 \\
\hline Living in the Centre & 0.184 & 0.147 & 1.3 & 1.445 & 0.811 & 1.8 \\
\hline cons & 1.939 & 0.912 & 2.1 & 11.757 & 4.989 & 2.4 \\
\hline N. obs. & 1341 & & & & & \\
\hline of which censored & & & & 1079 & & \\
\hline of which uncens. & & & & 262 & & \\
\hline Pseudo R2 & 0.11 & & & 0.06 & & \\
\hline
\end{tabular}




\section{Appendix 5 - Descriptive statistics for the panel 199-2000}

Table A5.1 - DESCRIPTIVE STATISTICS OF THE PANEL 1995-2000

(employees who worked more than 30 hours per week)

\begin{tabular}{|c|c|c|c|c|c|c|c|c|}
\hline \multirow[b]{2}{*}{ Variable } & \multicolumn{4}{|c|}{$\begin{array}{c}\text { Males } \\
(35 \% \text { worked overtime })\end{array}$} & \multicolumn{4}{|c|}{$\begin{array}{c}\text { Females } \\
(20 \% \text { worked overtime })\end{array}$} \\
\hline & Mean & S.D. & Mean & S.D. & Mean & S.D. & Mean & S.D. \\
\hline N. of overtime hours & 0 & 0 & 4.48 & 3.57 & 0 & 0 & 3.20 & 2.61 \\
\hline Standard hours (HSTAN) & 41.1 & 7.4 & 37.4 & 4.0 & 38.5 & 3.7 & 36.9 & 3.3 \\
\hline Hourly wage (HWAGE) & 13.63 & 5.66 & 13.85 & 4.19 & 12.64 & 3.79 & 13.57 & 3.94 \\
\hline Age & 40.09 & 10.36 & 40.23 & 8.51 & 40.10 & 8.67 & 39.46 & 9.35 \\
\hline N. of income earners & 2.09 & 0.89 & 1.99 & 0.88 & 2.28 & 0.73 & 2.24 & 0.59 \\
\hline Married & 0.74 & 0.44 & 0.85 & 0.35 & 0.75 & 0.44 & 0.68 & 0.47 \\
\hline $19<$ n. of employees in the firm $<50$ & 0.09 & 0.28 & 0.12 & 0.33 & 0.10 & 0.30 & 0.12 & 0.33 \\
\hline $49<$ n. of employees in the firm $<100$ & 0.07 & 0.25 & 0.07 & 0.25 & 0.08 & 0.26 & 0.09 & 0.29 \\
\hline $99<$ n. of employees in the firm $<500$ & 0.13 & 0.34 & 0.12 & 0.33 & 0.09 & 0.29 & 0.18 & 0.39 \\
\hline $499<\mathrm{n}$. of employees in the firm & 0.12 & 0.33 & 0.16 & 0.37 & 0.09 & 0.29 & 0.17 & 0.38 \\
\hline Public sector firm & 0.29 & 0.45 & 0.31 & 0.46 & 0.44 & 0.50 & 0.25 & 0.43 \\
\hline Elementary school diploma & 0.09 & 0.29 & 0.06 & 0.24 & 0.08 & 0.26 & 0.04 & 0.19 \\
\hline Middle school diploma & 0.40 & 0.49 & 0.41 & 0.49 & 0.28 & 0.45 & 0.24 & 0.43 \\
\hline High school diploma (3-4 years) & 0.40 & 0.49 & 0.47 & 0.50 & 0.50 & 0.50 & 0.53 & 0.50 \\
\hline High school diploma (5 years) & 0.09 & 0.29 & 0.06 & 0.24 & 0.13 & 0.34 & 0.20 & 0.40 \\
\hline Industrial sector & 0.31 & 0.46 & 0.42 & 0.49 & 0.25 & 0.43 & 0.29 & 0.46 \\
\hline Construction sector & 0.07 & 0.25 & 0.04 & 0.19 & 0.01 & 0.11 & 0.00 & 0.04 \\
\hline White collar - low level & 0.36 & 0.48 & 0.37 & 0.48 & 0.59 & 0.49 & 0.63 & 0.48 \\
\hline White collar - high level & 0.09 & 0.29 & 0.08 & 0.28 & 0.06 & 0.23 & 0.12 & 0.33 \\
\hline Manager & 0.04 & 0.19 & 0.02 & 0.13 & 0.01 & 0.08 & 0.02 & 0.15 \\
\hline Living in the North West & 0.22 & 0.41 & 0.27 & 0.44 & 0.24 & 0.43 & 0.34 & 0.48 \\
\hline Living in the North East & 0.20 & 0.40 & 0.33 & 0.47 & 0.29 & 0.45 & 0.26 & 0.44 \\
\hline Living in the Centre & 0.18 & 0.38 & 0.19 & 0.40 & 0.18 & 0.39 & 0.16 & 0.36 \\
\hline N. of obs. & 1157 & & 607 & & 650 & & 149 & \\
\hline
\end{tabular}




\section{IZA Discussion Papers}

No. Author(s)

541

542

543

544

545

546

547

548

549

550

551

552

553

554

555

556

557
B. Cockx

M. Dejemeppe

M. Frölich

J. Darby

R. A. Hart

P. Portugal

A. R. Cardoso

M. Fertig

C. M. Schmidt
A. M. Stiglbauer
F. Stahl
R. Winter-Ebmer
J. Zweimüller

G. S. Epstein

I. N. Gang

M. Frölich

E. Wasmer

D. Clark

T. Bauer

G. Epstein

I. N. Gang

R. Fahr

U. Sunde

S. Machin

P. A. Puhani

W. Koeniger

D. J. DeVoretz

H. Hinte

C. Werner

S. E. Black

E. Brainerd

G. C. Giannelli

C. Braschi
Title

Area

Date

Do the Higher Educated Unemployed Crowd Out 2

the Lower Educated Ones in a Competition for

Jobs

Programme Evaluation with Multiple Treatments

6

Wages, Productivity, and Work Intensity in the 5

Great Depression

Disentangling the Minimum Wage Puzzle: An

3

Analysis of Worker Accessions and Separations

The Role of Background Factors for Reading

6

Literacy: Straight National Scores in the PISA 2000 Study

Job Creation and Job Destruction in a Regulated 2

Labor Market: The Case of Austria

$08 / 02$

Government and Cities: Contests and the

3

08/02

Decentralization of Decision Making

What is the Value of Knowing the Propensity

Score for Estimating Average Treatment

Effects?

Interpreting Europe and US Labor Markets

Differences: The Specificity of Human Capital

Investments

The Impact of Local Labour Market Conditions

5

$08 / 02$ on Participation in Further Education in England

Herd Effects or Migration Networks?

08/02

The Location Choice of Mexican Immigrants in the U.S.

Estimations of Occupational and Regional

08/02

Matching Efficiencies Using Stochastic

Production Frontier Models

Subject of Degree and the Gender Wage

2

08/02

Differential Evidence from the UK and Germany

Employment Protection, Product Market

3

08/02

Competition and Growth

How Much Language is Enough?

08/02

Some Immigrant Language Lessons from

Canada and Germany

Importing Equality? The Impact of Globalization

08/02

on Gender Discrimination

Reducing Hours of Work: Does Overtime Act as

a Brake Upon Employment Growth?

\section{2}

$8 / 02$

$8 / 02$

$8 / 02$

$8 / 02$ 